2004.

- MARIN, José. Dimensión histórica de la perspectiva intercultural: educación, Estado y sociedad. In: Revista Grifos: Dossiê Educação Intercultural. Chapecó, SC: Argos, 2004, p. 69-88

- PAULA, Eunice Dias de. "A interculturalidade no cotidiano de uma escola indígena". In: Cadernos Cedes, ano XIX, no 49, Dezembro, 1999.

- UNESCO. 1980. Colloque sur lês "Phénomènes d'acculturation et de déculturation dans le monde contemporain" em: http://unesdoc.unesco. org/images/0009/000939/093953fb.pdf. Acesso em: 10 de jul. de 2011.

- VARRO, Gabrielle. 'Les présupposés de la notion d'interculturel Réflexions sur l'usage du terme depuis trente ans'. em: http://ressources-cla.univfcomte.fr/gerflint/chili3/varro.pdf. Acesso em: 9 de jul. de 2011.

\section{Warna Vieira Rodrigues}

Antropóloga. Estudiante de maestría en antropología en la Universidad Federal de Pernambuco, Diploma de Postgrado en Antropología Social y en la historia de Europa en la EHESS, Toulouse. Tiene experiencia en investigación en las áreas de la población indígena en Pernambuco. Professora da rede de ensino no Recife y de la Facultad de Recife Frassinetti - FAFIRE

\section{Alice Ferreira do Nascimento Maciel}

Estudiante de maestría en antropología en la Universidad Federal de Pernambuco. Tiene experiencia en investigación en las áreas de la población rural en Brasil. Ha desarrollado investigaciones en las poblaciones acerca de la Extensión Rural para las comunidades tradicionales, llamadas comunidades quilombolas. Es miembro de la Red de Estudios Rurales y del Laboratorio de Estudios Rurales de la UFPE.
EDUCAÇÃO ESCOLAR

INDÍGENA: A EDUCAÇÃO

POPULAR COMO ESTRATÉGIA

PARA MANUTENÇÃO DA CULTURA

NA ESCOLA INDÍGENA FULNI-Ô

MARECHAL RONDON DO POVO

FULNI-Ô - AGUAS BELAS -

PERNAMBUCO - BRASIL

Simone Cristina Cavalcante sicriscal@hotmail.com

\section{RESUMO}

O presente artigo analisa a Educação Escolar Indígena na Escola Indígena Fulni-ô Marechal Rondon e suas ações pedagógicas direcionadas pela pedagogia da Educação Popular como uma das estratégias para manutenção da cultura do povo Fulni-ô localizado município de Águas Belas - Pernambuco - Brasil, partindo de tal análise e de acordo com a metodologia qualitativa, apresentamos a identificação do seu processo de luta para manutenção e fortalecimento de sua cultura através da educação escolar.

Palavras-chave: Educação Escolar Indígena. Educação Popular. Escola Indígena Fulni-ô Marechal Rondon.

\section{SUMMARY}

This article analyzes the Indigenous Education Indigenous School Fulni-ô Marshal Rondon and his actions directed by the teaching pedagogy of popular education as a strategy to maintain the culture of the people Fulni-ô in the city of Águas Belas - Pernambuco - Brazil starting from this analysis and according to the proposed methodology qualitative aspect, we present the identification the struggle for its maintenance and strengthening of their culture, through school education.

Keywords: Indigenous School Education. Popular Education. Indigenous Fulni-ô 
Marshal Rondon School.

\section{INTRODUÇÃO}

P

ara se falar em Educação Escolar Indígena no Brasil faz-se necessário voltar no tempo para que se percebam as mudanças ocorridas com a instituição escolar entre os povos indígenas desde a escola catequizadora até os direitos garantidos na Constituição de 1988 e as lutas e reivindicações atuais. Lutas e reivindicações estas travadas no cotidiano de fazer valer aquilo que se tem enquanto legislação, cabendo aos povos indígenas fazer valer seus direitos e aos professores indígenas em seu trabalho pedagógico contribuir neste processo. Neste sentido a construção de conhecimentos proposta pela Educação Escolar Indígena baseada nas ações pedagógicas da pedagogia da Educação Popular objetiva tornar o indivíduo conhecedor de seus direitos e deveres por meio do resgate de sua cidadania, através do estudo de sua história, de sua cultura, neste sentido, o presente artigo tem como objetivo analisar como a comunidade escolar da Escola Indígena Fulni-ô Marechal Rondon localizada no município de Águas Belas - PE. - BR. utiliza a Educação Escolar Indígena para manutenção de sua cultura e de que forma a Educação Popular tem contribuído neste processo e até que ponto pode-se considerar a Educação Popular como uma das estratégias para manutenção da cultura da etnia, dada a especificidade do grupo e o contexto étnico, social e cultural, e sua luta para manterem-se enquanto índios e por uma educação especifica, diferenciada, intercultural e bilíngüe.

\section{Educação Escolar Indígena e Educação Popular no Brasil}

A Educação Escolar Indígena no Brasil atravessou historicamente quatro fases distintas, caracterizadas por diferentes encaminhamentos e diretrizes políticas e ideológicas.

A primeira fase ocorreu com o processo colonizador, estando basicamente sob a responsabilidade de missionários jesuítas portugueses. A escolarização era apenas um instrumento de catequese, de cristianização do índio, que era "pacificado" e sua mão de obra escravizada para ajudar a construir o projeto colonial, no qual se tinha uma escola "civilizadora" de índios, desvalorizando as diferentes culturas indígenas que foram consideradas importantes pelos colonizadores, apenas para a condução desse processo de submissão.

A segunda fase foi marcada pela criação do SPI ( Serviço de Proteção ao Índio) em 1910, com o Estado brasileiro implementando uma política indigenista de "integração" à sociedade nacional, pois o índio era visto numa condição étnica inferior. Todo esse pensamento de "civilizar" e de "integrar" os povos indígenas à sociedade nacional, herança deixada pelos colonizadores, influenciou a visão do Estado, através da legislação e da política indigenista, criando uma tutela assistencialista de caráter dependente o que perdurou por anos.

A terceira fase da Educação Escolar Indígena no Brasil inaugura-se com a extinção do SPI em fins da década de 1960 e criação da Fundação Nacional do Índio (FUNAI) em 1967, além da criação de diversas Organizações Não Governamentais (ONGs) de apoio às causas indígenas. Em 19 de dezembro de 1973 foi promulgada a Lei 6001, denominada de Estatuto do Índio, estatuto marcado pela intenção integracionista dos índios à comunhão nacional, pois com relação a educação para os povos indígenas o Artigo 50 do Estatuto do Índio de 1973diz expressamente que: "A educação do índio será orientada para a integração na comunhão nacional mediante processo de gradativa compreensão dos problemas gerais e valores da sociedade nacional bem como do aproveitamento das suas aptidões individuais".

A quarta fase tem início na década de 1980 com o chamado movimento indígena fruto do surgimento e consolidação de diversas organizações de educadores indígenas dando início a um movimento de criação de diferentes experiências escolares indígenas e de formação de educadores, apoiados por diversas instituições de assessoria. Nessa fase a escola passou a ser pensada dentro dos direitos humanos e sociais, pois com a Constituição Federal do Brasil de 1988 "São reconhecidas aos índios sua organização social, costumes, línguas e tradição e os direitos sobre as terras que tradicionalmente ocupam, competindo à União demarcá-las, proteger e fazer respeitar todos os seus bens", conforme a Constituição Federal Brasileira (1988, Art. 231). Contudo os direitos educativos e lingüísticos também passam a estar garantidos pelo poder público, no capítulo sobre o Ensino Fundamental, pelo qual "é facultado às comunidades indígenas a utilização de suas línguas maternas e processos 
próprios de aprendizagem" (idem, Art. 210).

A Constituição Federal Brasileira de 1988 representa o primeiro texto que explicita a relação do Estado com os povos indígenas, reconhecendo a diversidade étnica e o respeito à diferença, afastando-se, desse modo, do caráter integracionista preconizado durante vários séculos, em todo o país, abrindo a possibilidade de construção de uma escola verdadeiramente indígena, como instrumento de valorização das culturas indígenas, deixando de ser mais um meio de imposição dos valores e das normas de outras culturas.

Sabemos que a década de 1990 foi marcada pela aceleração das discussões e propostas legais de regulamentação de educação escolar nas comunidades indígenas no Brasil. A partir da promulgação da Constituição Federal em 1988 surge a Lei n. 9.394, de 20/12/96 Lei de diretrizes e Bases da Educação (LDB) que instituiu como dever do Estado a oferta de uma educação escolar bilingüe e intercultural e uma legislação regulamentar. Em seguida a Resolução № 3, do Conselho Nacional de Educação (CNE) de 1999 a qual veio estabelecer Diretrizes Curriculares Nacionais e fixar normas para o reconhecimento e funcionamento das escolas indígenas, acrescenta-se a estas a criação e publicação dos Referenciais Curriculares Nacionais para as Escolas Indígenas (RCNEI) em 1998, além das inúmeras publicações de livros apoiados e financiados pelo MEC e de decretos e leis que foram criadas, além da realização de projetos e formações de professores indígenas com financiamento público e com a participação de universidades e Organizações Não Governamentais (ONGs).\{

Segundo Meliá (1981, p. 10): “Logo a pedagogia do oprimido vai sendo aplicada com bons resultados na situação específica do índio. Usam-se recursos expressivos e didáticos mais apropriados ao sistema indígena", visto que a Educação Popular exprime um conteúdo que se origina na realidade, adquirindo diferenciadas modalidades de trabalho pedagógico, pois ele está dirigido e dirigindo e se dirigindo para os moradores de periferias de cidades, aos camponeses e aos indígenas, neste sentido a educação diferenciada voltada para as populações indígenas pressupõe uma constante reflexão de sua prática pedagógica, constituindo-se em um processo que tem como ponto de partida e de chegada a perspectiva das comunidades indígenas, nela buscase a afirmação étnica de cada povo, valorizando as línguas, os costumes e as tradições.
Atualmente a Educação Escolar Indígena caminha para uma nova fase que se caracteriza as pela incorporação das reivindicações dos povos indígenas nas diretrizes e princípios da legislação que orienta a política educacional para esses povos. O processo de luta por uma Educação Escolar Indígena verdadeiramente cidadã é revestido por seu caráter de luta, luta esta por uma melhoria e pela garantia de direitos na lei e hoje, mais do que nunca, por se fazer valer na prática o que já esta garantido no papel.

\section{Metodologia da Pesquisa}

O presente artigo apresenta uma análise da Educação Escolar Indígena na Escola Indígena Fulni-ô Marechal Rondon localizada no aldeamento Fulni-ô no município de Águas Belas - PE - Brasil, destacando seu caráter de manutenção cultural na sua luta pela resistência, onde a Educação Popular se faz presente. Para tanto a metodologia adotada teve por base o caráter qualitativo. A pesquisa foi desenvolvida no período de dezembro de 2009 a maio de 2011, onde foram realizadas 70 visitas a escola pesquisada. A população utilizada foi a Comunidade Escolar da Escola Indígena Fulni-ô Marechal Rondon localizada no aldeamento indígena Fulni-ô no município de Águas Belas - PE - BR com um total de 1497 estudantes, 72 professores e 7 coordenadores pedagógicos, sendo que a etnia tem uma população total de 4.383 indivíduos. Para a amostra foram entrevistados 21 professores e 1 coordenador pedagógico, 45 estudantes, 1 representante da liderança Fulni-ô, neste caso o pajé e por 10 pessoas da comunidade escolar (escolhidas de forma aleatória durante a pesquisa de campo). Os dados foram coletados através de pesquisa documental, observação do cotidiano escolar e realização de entrevistas gravadas em MP3. De posse dos dados fizemos uma análise e os resultados foram discutidos em correlação com a fundamentação teórica efetivada para este estudo.

A Educação Popular como Estratégia para Manutenção da Cultura na Escola Indígena Fulni-ô Marechal Rondon

A Escola Indígena Fulni-ô Marechal Rondon teve sua origem a partir de 1928 por iniciativa do chefe do Posto Indígena General Dantas Barreto do Aldeamento Fulni-ô, o Sr. Alberto Jacobina, trazido pelo Monsenhor Alfredo Damaso, sendo assim foi construída em 1929 a Escola General Rondon que era mantida pelo SPI. A construção dessa escola para a comunidade surgiu da necessidade de 
atender a demanda da população indígena que a cada dia crescia e necessitava estudar. A escola passou a ser denominada de Escola Marechal Rondon, em homenagem ao Marechal Rondon, sobretudo pelo trabalho que realizou junto aos índios do Brasil. Através do Decreto no 24.628 de 12 de agosto de 2002, a Escola Indígena Fulni-ô Marechal Rondon passou a fazer parte da rede Estadual de Pernambuco.

Podemos identificar a importância da chegada da escola na aldeia diante das necessidades da etnia Fulni-ô, porém a função dessa escola, a princípio, era o de incluir o índio a sociedade nacional e não tinha nada de especifico e diferenciado, conforme corrobora a professora da escola pesquisada Santos (2010):

A Escola General Rondon nasceu com a chegada do SPI a nossa aldeia em 1922, essa era uma escola extremamente rigorosa, e não admitia jamais aspectos culturais na sua organização, pois ela surge para incluir o índio na sociedade nacional, então tinha nada de específico nem de diferenciado.

Nos últimos anos ocorreram significativas mudanças no tratamento da temática educacional indígena, pois os próprios índios entraram em cena para debater a política de escolarização e para exigir uma educação escolar voltada ao atendimento dos seus interesses, com isso a educação escolar indígena passou a ser vista como uma política pública e como um direito de cidadania. Segundo a professora Souza (2010):

A conquista de uma escola na nossa aldeia foi um marco para o povo, pois era grande a necessidade dos índios se integrarem as outras culturas e afirmar a sua. Uma das maiores conquistas da nossa história foi o próprio índio se tornar condutor da sua educação.

A Educação Escolar Indígena tem que ser necessariamente específica e diferenciada, intercultural e bilíngüe com isso podemos afirmar que o etnoconhecimento é peça fundamental na proposta de construção de uma escola indígena, a qual seja mais que uma escola de brancos pensada para índios, ou seja, que incorpore o saber dos anciãos, as características da educação indígena ancestral integrada à prática da educação libertadora. É essa mesma escola na luta por uma prática educativa libertadora que encontramos a Escola Indígena Fulni-ô Marechal Rondon e isso podemos comprovar nas afirmativas da professora Rocha (2010):

A luta do povo Fulni-ô por uma escola indígena especifica diferenciada intercultural e bilíngüe deu-se diante da necessidade do povo de uma educação que respeitasse sua cultura no caso de nós, os índios Fulni-ô, essa cultura precisa ser valorizada, precisa está diariamente sendo trabalhada dentro das nossas escolas pra que com o passar do tempo não venhamos perdê-la, pois diante do contato direto com o não índio [...]. Trabalhando mais a nossa cultura dentro das escolas é uma forma de chamar a atenção dos alunos mais novos das novas gerações pra que nossa cultura não venha a se perder ou não se modifique totalmente.

A proposta da educação escolar indígena específica, diferenciada, intercultural e bilíngüe é a de incorporar nas atividades da escola a própria comunidade, os idosos com seus saberes e ensinamentos, ou seja, derrubar os muros da escola, pois segundo Freire (1987, p. 39) em sua obra Pedagogia do Oprimido: "ninguém educa ninguém. Ninguém educa a si mesmo. Os homens se educam entre si mediatizados pelo mundo", logo a educação escolar indígena compreende os processos pelos quais esses povos asseguram seus projetos de futuro, reproduzindo e reconstruindo a identidade, a tradição, os saberes, os valores, os padrões de comportamento e de relacionamento, na dinâmica própria de suas culturas. Sendo assim, a educação é um processo que ocorre de modos distintos e por meio de pedagogias e mecanismos próprios em cada cultura. Os povos indígenas possuem espaços e tempos educativos dos quais participam a pessoa, a família, a comunidade e todo o povo, deste modo a educação escolar da escola pesquisada é assumida como responsabilidade coletiva, conforme corrobora o texto da Proposta Pedagógica da Escola Indígena Fulni-ô Marechal Rondon (2009/2010, p. 8):

A Escola Indígena Fulni-ô Marechal Rondon, através de uma ação coletiva envolvendo lideranças, pais, professores, alunos e a comunidade à luz de relatos de experiências pelos mais velhos, bem como orientados pela Resolução do CNE № 03 de 07/04/98, 
que ressalta a importância da organização dos trabalhos administrativos e pedagógicos das instituições Escolares como forma de qualificar o processo ensino-aprendizagem, elabora a sua Proposta Pedagógica priorizando uma ação educativa centrada no compromisso docente, no planejamento participativo e, sobretudo, em atender as necessidades dos alunos e de sua comunidade escolar, visando seu crescimento e melhoria.

Percebemos que a educação escolar indígena diferenciada é um instrumento de resistência e luta, porém para torná-la possível não basta rever apenas as práticas pedagógicas, os calendários, os currículos, mas, sobretudo, as posturas etnocêntricas em que se baseiam. Para que isso seja possível à educação escolar deve ser praticada no interesse de cada grupo indígena e com a valorização de seus etnoconhecimentos já na elaboração e na execução dos projetos de escola.

A organização curricular da proposta pedagógica da escola pesquisada referencia-se nas Diretrizes Curriculares Nacionais para o Ensino Fundamental, assim como na Base Curricular Comum para as Redes Públicas de Ensino de Pernambuco, nas Diretrizes Curriculares Nacionais para a Educação Escolar Indígena, considerando o RCNEI, neste sentido, a Proposta Pedagógica da Escola Indígena Fulni-ô Marechal Rondon é um documento que se constitui num instrumento valioso para a organização dos programas curriculares na escola, sendo de responsabilidade de todos os seus atores e seu objetivo geral

Articular as dimensões sócias históricas e culturais da Escola Indígena Fulni-ô Marechal Rondon ao processo de ensino aprendizagem a partir da sistematização de objetivos, conteúdos, metodologias, critérios de avaliação e competências necessárias, para elevar o nível de conhecimento do aluno, a competência profissional dos docentes e funcionários e especialmente, a qualidade da educação oferecida pela referida escola (PROPOSTA PEDAGÓGICA DA ESCOLA INDÍGENA FULNI-Ô MARECHAL RONDON, 2009/2010, p. 21).

Por isso a organização curricular da escola pesquisada é composta pelas disciplinas da base nacional comum que é complementada por uma parte diversificada conforme determina a LDB. Assim observamos que a formalização da proposta pedagógica da escola pesquisada apresenta a formalização da proposta educacional que tem por base o caráter do real diálogo intercultural e todas as suas implicâncias, considerando que o estado deve reconhecer e respeitar as diferentes formas de viver e ter direito a cidadania e a educação escolar digna e de qualidade. Por isso a proposta educacional não pode ser um projeto como esses que vêm de fora ela surge desde dentro, baseada nas próprias formas de organizar o mundo e a vida do povo Fulni-ô.

Neste sentido, os saberes trabalhados na escola pesquisada, apresentam-se como conhecimento historicamente elaborado e sistematizado, considerando a relação ensino aprendizagem, a experiência do educando e o seu contato com o conhecimento empírico presente no seu cotidiano, priorizando assim, a realidade do educando, do educador, da comunidade e da escola, apresentamos no anexo A o Detalhamento Curricular da Escola Indígena Fulni-ô Marechal Rondon que se estrutura a partir dos eixos temáticos da Educação Escolar Indígena (Terra, História, Organização, Identidade, Interculturalidade e Bilinguismo), possibilitando ao educando desenvolver habilidades conceituais, atribuindo significados as situações do cotidiano escolar tornando-se competente para construir seu projeto de vida cidadã e agir com competência nas relações sociais e no mundo do trabalho.

Nessa ótica, a escola tem sido entendida como um lugar onde a relação entre os conhecimentos próprios de cada cultura e os novos conhecimentos, advindos do contato intercultural, poderão se articular. 0 espaço escolar indígena também é uma possibilidade de informação a respeito da sociedade nacional, favorecendo o diálogo interétnico, o confronto de diferentes lógicas, projetos e perspectivas e a construção de relações igualitárias fundamentadas no respeito, reconhecimento e valorização das diferenças culturais entre os povos indígenas a sociedade civil e o Estado.

Na escola pesquisada há um trabalho pedagógico que assegura a comunidade indígena Fulni-ô a preservação da identidade do povo e unindo os conhecimentos científicos ao etnoconhecimento dos estudantes, dos docentes e da comunidade, fortalecendo assim a cultura da etnia. Para que isso aconteça o professor tem papel desafiante e articulador para tornar a Educação Escolar Indígena indispensável ao progresso de seu povo, em direção aos mais nobres 
ideais, transformando a escola em um espaço privilegiado para análise, discussão e reflexão da realidade contribuindo para sua formação cidadã conforme afirma a professora indígena da escola pesquisada Rocha (2010):

A escola tem trabalhado a formação da consciência cidadã, pois trabalhamos nossos alunos, seus direitos, onde é seu lugar dentro da sociedade não indígena e dentro da sociedade indígena. Trabalhamos eles de uma forma que eles aprendam quais são seus direitos tanto como cidadão índio, como cidadão da sociedade não-índia para que eles cresçam e saibam que como se portar dentro das duas culturas e não se perca nem como indígena, nem como cidadão da sociedade dominante, isso é importante porque vem a fortalecer nossa cultura sempre.

Sendo assim, observarmos que a missão da Escola Indígena Fulni-ô Marechal Rondon é a de formar estudantes indígenas atuantes na sociedade índia e nãoíndia, a partir da valorização de sua identidade e das ações pedagógicas de uma escola indígena especifica diferenciada, intercultural e bilíngüe, pois o povo Fulni-ô é o único povo indígena do nordeste que mantém sua língua materna, o Yaathê e em sua educação escolar valoriza seu ensino como estratégia de resistência cultural. Por isso sabemos da importância de se colocar no currículo indígena conteúdos sobre a cultura dos povos indígenas e isso deve ser feito para que as tradições sejam sempre lembradas, por tudo isso a etnia Fulni-ô sempre afirma que falar a língua Yaathê é muito importante, visto que junto com o ritual do Ouricuri ela representa a identidade do índio Fulni-ô, pois diante do intenso contato com o não-índio a língua indígena pode ser ameaçada.

A escola tem um Calendário Escolar Diferenciado (ver anexo B ), o qual é elaborado de acordo com o ritual sagrado do povo Fulni-ô, o ritual do Ouricuri, conforme corrobora Rocha (2010): "O nosso calendário escolar ele é diferenciado nos começamos as aulas no início de dezembro, pois é quando saímos do nosso ritual sagrado e terminamos no fim do mês de agosto que é em setembro que começa o nosso ritual".

A Escola Indígena Fulni-ô Marechal Rondon atua como escola de referencia na oferta de uma educação escolar indígena específica, diferenciada, intercultural e bilíngüe, por seu ensino comprometido com a cidadania e com os hábitos culturais do povo Fulni-ô, buscando assim a formação para cidadania. Logo a orientação da Pedagogia Libertadora de Paulo Freire combina com as especificidades da cultura Fulni-ô que valoriza o aprendizado sobre o papel da ancestralidade na educação, pois a ancestralidade faz parte do processo identitário na Escola Indígena Fulni-ô Marechal Rondon, com isso observamos que ela possibilita a ligação do indivíduo com sua comunidade e assim sua leitura de mundo, dos outros e de si mesmo.

Logo a ancestralidade pode ser vista como a procura, no passado, daquilo que dar sentido à vida hoje, pois para o povo Fulni-ô o futuro não é um caminho unilinear, ele é um constante e eterno retorno ao passado e aos ancestrais. Por isso verificamos o grandioso respeito aos anciãos da etnia e o eterno amor pelo ritual do Ouricuri, neste sentido a educação da escola pesquisada é fundamentada na tradição e na memória histórica coletiva que é atualizada na palavra dos mais velhos, sendo que estes nunca repreendem seus aprendizes, mas com seu exemplo mostram a forma correta, neste sentido o ato pedagógico primordial é a ação de quem ensina, porque pressupõe o exemplo, logo ensinar é fazer junto.

O pajé da etnia Fulni-ô e professore de língua materna da escola pesquisada o Sr. Gildiere Ribeiro Pereira (2011) diz que:

É de grande importância levar a cultura dos nossos antepassados pra escola, porque hoje em dia o jovem mantém contato direto com o não-índio e assim se influencia com uma cultura que não é nossa. E a escola é um local onde nós encontramos uma grande quantidade de jovens índios e o local ideal para dar continuidade a uma cultura milenar que é fruto da continuidade da essência Fulni-ô não dispensando a família como principal repasse da cultura é de suma importância incluir no trabalho educativo das nossas crianças que são o futuro da nossa aldeia conteúdos como as tradições culturais. A contribuição das lideranças é a de conscientizar para manter viva a responsabilidade de dar continuidade a nossa cultura.

Com isso, observamos que na escola pesquisada os costumes e as tradições estão ligadas ao processo de ensino e aprendizagem, pois no dinamismo da 
cultura Fulni-ô, a referida escola vai sendo apropriada e ressignificada pela intervenção da coletividade, ela apresenta a prática da educação popular em seu cotidiano, refletindo assim o que o que dizia Paulo Freire ao estabelecer como base para a ação pedagógica a leitura de mundo, o conceito e prática propostos a partir da noção de temas geradores em consonância com a importância da valorização do conhecimento prévio dos educandos e educadores, configuramse como referência ideal para uma práxis educativa com métodos e técnicas adequados para trabalhar com a diversidade da população brasileira e neste caso especifico, da etnia Fulni-ô.

Ao observarmos a realidade da Escola Indígena Fulni-ô Marechal Rondon notamos a relação ao trabalho do professor indígena Fulni-ô, que em seu contato com sua comunidade e sendo conhecedor de sua realidade, busca introduzir a cultura e a participação da comunidade na realização de seu trabalho pedagógico, conforme afirma o professor Torres (2010):

Nós, professores, junto com a coordenação geral e a coordenação pedagógica escolhemos conteúdos [...] com a questão histórica, com a questão da identidade, questão de organização, com a questão da língua. Ao colocarmos na prática esses conteúdos utilizamos recursos tecnológicos e conhecimentos populares da comunidade, pois os conteúdos que nós selecionamos vão de encontro a nossa cultura, pois eles favorecem a cada dia o fortalecimento e o conhecimento dessa cultura milenar existente no povo Funi-ô [...] realizamos pesquisas dentro da comunidade [...] isso é possível: aprender dentro da comunidade com as lideranças, com os mais velhos, isso é muito importante trabalhar a cultura na sala de aula porque constrói a formação cidadã.

Por tudo isso, a Escola Indígena Fulni-ô apresenta como compromisso a afirmação da identidade do povo Fulni-ô e por isso busca em sua pedagogia baseada na Educação Popular, ser um instrumento de interculturalidade na formação do cidadão indígena Fulni-ô ligado as tradições de seu povo e nas lutas pelo reconhecimento e valorização de sua identidade étnica diante das demandas da sociedade não-índia, sendo assim a escola é a porta de entrada para o mundo fora da aldeia. Neste sentido, a escola ganha o interesse dos índios, pois segundo Grupioni (apud JANUÁRIO, 2002, p. 19): “a grande demanda é conhecer o mundo do branco: os códigos, os valores. É preciso dar condições para que se estabeleça esse contato de forma positiva e enriquecedora".

A educação escolar indígena deve representar o caminho para o reconhecimento da cidadania plena e para o respeito à diferença. A partir desta pesquisa constatamos que a Escola Indígena Fulni-ô Marechal Rondon apresenta como forte característica a prática da Pedagogia Libertadora da Educação Popular como estratégia pra manutenção e fortalecimento cultural do povo Fulni-ô, pois a tradição é a fonte da educação na busca da construção do cidadão indígena Fulni-ô, através das socializações, pois como afirma Durkheim (1976, p. 39): "Para que haja educação, faz-se mister que haja, em face uma geração de adultos, uma geração de indivíduos jovens, crianças e adolescentes; e que uma ação seja exercida pela primeira sobre a segunda". Conforme corrobora Torres (2010):

A Escola Indígena Fulni-ô Marechal Rondon trabalha principalmente a formação da consciência cidadã dos nossos alunos, conhecendo seus direitos nas legislações como indígena e não-indígena. A garantia desses direitos aos indígenas Fulni-ô são vivenciadas dentro do cotidiano ao trabalhar respeito e cidadania. Isso é vivenciado no cotidiano escolar dos nossos alunos de uma forma dinâmica, fazendo com que eles conheçam o seu papel na sociedade indígena e não indígena. A comunidade de um modo geral ver esse trabalho de uma forma significativa. É importante trabalhar isso o lema da nossa escola é: nós professores temos o papel de formar indígenas com a flecha em uma mão e o diploma na outra.

Tudo isso podemos observar não apenas na fala dos professores, como também nas afirmações dos estudantes, sendo assim vale destacar o que diz a estudante da Escola Indígena Fulni-ô Pontes (2010):

A Escola Indígena Fulni-ô Marechal Rondon representa muito para minha vida, pois ela traz o ensino diferenciado para meu povo. Aqui na Escola os conteúdos estão relacionados a minha cultura, o calendário das aulas respeita meu ritual religioso, o Ouricuri e isso é muito importante para nós índios Fulni-ô, o respeito e 
a valorização de nossa cultura na escola [...] aqui aprendemos a nossa cultura para nos impor enquanto índio Fulni-ô diante da sociedade não-índia.

Observamos que a escola pesquisada em suas ações pedagógicas considera a formação cidadã Fulni-ô consciente da importância de sua cultura e do respeito e valorização da cultura não-índia, ou seja, o diálogo intercultural que é uma das exigências para que se faça uma educação escolar indígena de qualidade, visto que a escola é o instrumento fundamental para a socialização deste diálogo. Diante da análise de tudo que aqui foi analisado, podemos afirmar que continua, nos dias atuais, a luta por novas conquistas na Escola Indígena Fulni-ô Marechal Rondon, objetivando manter-se como escola verdadeiramente indígena, especifica, diferenciada, intercultural e bilíngüe, buscando sempre ser mantenedora, defensora e fortalecedora da cultura do seu povo, valorizando a participação de toda a etnia nas ações pedagógicas, primando pelo diálogo interétnico e a formação do cidadão Fulni-ô.

\section{Considerações Finais}

Com a realização do presente estudo constatamos que a Educação Popular tem contribuído no processo de manutenção da cultura do povo Fulni-ô, pois a realidade da escola pesquisada destaca seu caráter de manutenção cultural na sua luta pela resistência, onde a Educação Popular se faz presente nas ações pedagógicas o que foi constatado neste estudo a partir das observações feitas na escola pesquisada e a partir das afirmativas dos professores, educandos, coordenadores pedagógicos, da liderança e da comunidade coletadas nas entrevistas.

Com isso verificamos que todo o povo Fulni-ô é importante na execução das ações pedagógicas e dessa forma contribui com o projeto societário e de continuidade cultural, definidos com autonomia a partir de seus saberes, valores e práticas sociais e culturais, característica própria da pedagogia da Educação Popular. Neste sentido, a proposta pedagógica construída com autonomia pela comunidade escolar da Escola Indígena Fulni-ô Marechal Rondon a partir da participação comunitária se articula com o fortalecimento da cidadania indígena, pois a educação escolar indígena compreende os processos pelos quais os indígenas asseguram seus projetos de futuro, reproduzindo e reconstruindo a identidade, a tradição, os saberes, os valores, os padrões de comportamento e de relacionamento, na dinâmica própria de suas culturas.

A educação escolar na escola pesquisada é um processo que ocorre de modos distintos e por meio de pedagogias e mecanismos próprios da cultura da etnia, pois o povo indígena Fulni-ô possui seus espaços e tempos educativos, nos quais participam a família, as lideranças, a comunidade e toda a etnia. Deste modo, a educação é assumida como responsabilidade coletiva, sendo assim a escola é um projeto comunitário e o reconhecimento dessa autonomia passa por uma negação do modelo assimilacionista de educação implementado desde a época colonial, porém a Educação Escolar oferecida aos povos indígenas no Brasil ao longo desses 511 anos obteve avanços significativos, pois a princípio ela foi uma escola catequizadora, passando posteriormente a escola integradora, e homogeneizante, mas após muita luta e reivindicação os povos indígenas obtiveram conquistas nas Bases Legais, porque a partir da Constituição Federal do Brasil de 1988 foram criadas leis, decretos e resoluções que garantem, hoje, aos povos indígenas uma escola indígena especifica, diferenciada, intercultural e bilíngüe. \{

A partir do presente estudo verificamos que a Escola Indígena Fulni-ô Marechal Rondon (fundada em 1928) busca garantir o fortalecimento da identidade étnica do povo Fulni-ô, através de suas ações pedagógicas voltadas para a história da etnia, valorizando sua cultura e desenvolvendo um trabalho direcionado a interculturalidade. Constatamos que tudo isso é possível graças ao fortalecimento e a autonomia pedagógica da escola que se apresenta em sua proposta pedagógica, em seu calendário diferenciado e em seu currículo intercultural, neste sentido a participação efetiva da comunidade e das lideranças no apoio as ações pedagógicas mostra que a Escola Indígena Fulni-ô Marechal Rondon tem cumprido seu papel de escola indígena pensada, elaborada e gerenciada pelo povo Fulni-ô de acordo com seus anseios e modos de organização política e social, voltada para seu futuro sem perder de vista sua história e sua cultura.

\section{Referências Bibliográficas}

- BRASIL, Constituição da República Federativa do. Artigos 210 e 231. Senado Federal. Brasília, 1988 
- DURKHEIM, Émile. A educação como processo socializador. Função Homo-geneizadora e função diferenciada. Educação e sociedade. 70 ed. São Paulo: Companhia Editora Nacional, 1976.

- ESTATUTO DO ÍNDIO, Lei ordinária № 6001, de 19 de dezembro de 1973. Artigo 50. Brasília, 1973.

- FREIRE, Paulo. Pedagogia do oprimido. 170 ed. Rio de Janeiro: Paz e terra, 1987.

- JANUÁRIO, Elias. Ensino superior para índios: um novo paradigma na educação. Cadernos de Educação Escolar Indígena - 3o grau indígena. 1을 ed. Barra do Bugres: Unemat, 2002.

- MELIA, B. Traçados da Educação indígena. In: Silva Aracy Lopes da (org.). A questão da Educação Indígena. São Paulo: Brasiliense, 1981.

- PEREIRA, Gildiere Ribeiro. Entrevista concedida pelo pajé da etnia Fulni-ô e professor de Yaathê da Escola Indígena Fulni-ô Marechal Rondon. Águas Belas - PE. Fonte Oral, 2011.

- PONTES, Priscila. Entrevista concedida pela estudante da Escola Indígena Fulni-ô Marechal Rondon. Águas Belas - PE. Fonte Oral, 2010.

- PROPOSTA PEDAGÓGICA DA ESCOLA INDÍGENA FULNI-Ô MARECHAL RONDON. Ano Base 2009/2010.

- ROCHA, Rosinete da Cunha. Entrevista concedida pela professora. Águas Belas - PE. Fonte Oral, 2010.

- SANTOS, Milene Sarapó dos. Entrevista concedida pela professora. Águas Belas - PE. Fonte Oral, 2010.

- SOUZA, Paula Francisca de. Entrevista concedida pela professora. Águas Belas - PE. Fonte Oral, 2010.

- TORRES, Expedito Lino. Entrevista concedida pelo professor. Águas Belas PE. Fonte Oral, 2010.

\section{Simone Cristina}

Mestra em Ciências da Educação pela Universidade Tecnológica Intercontinental

do Paraguai - UTIC em julho de 2011.

\section{ANEXOS}

Anexo A: Detalhamento Curricular da Escola Indígena Fulni-ô Marechal Rondon.

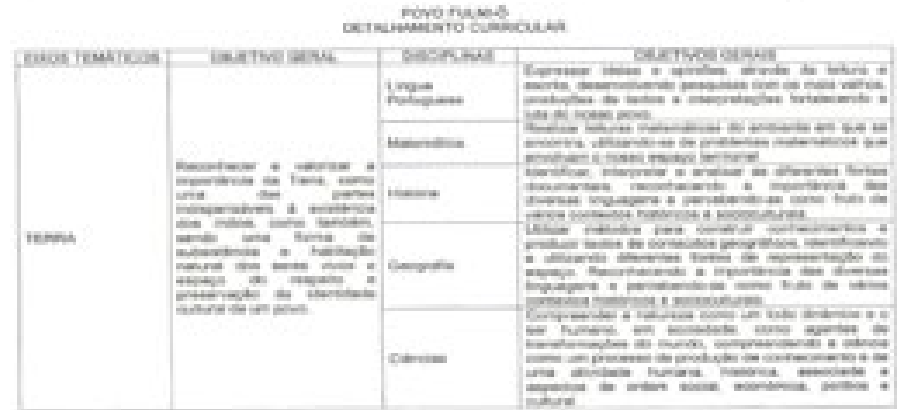

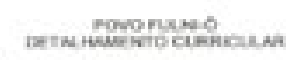

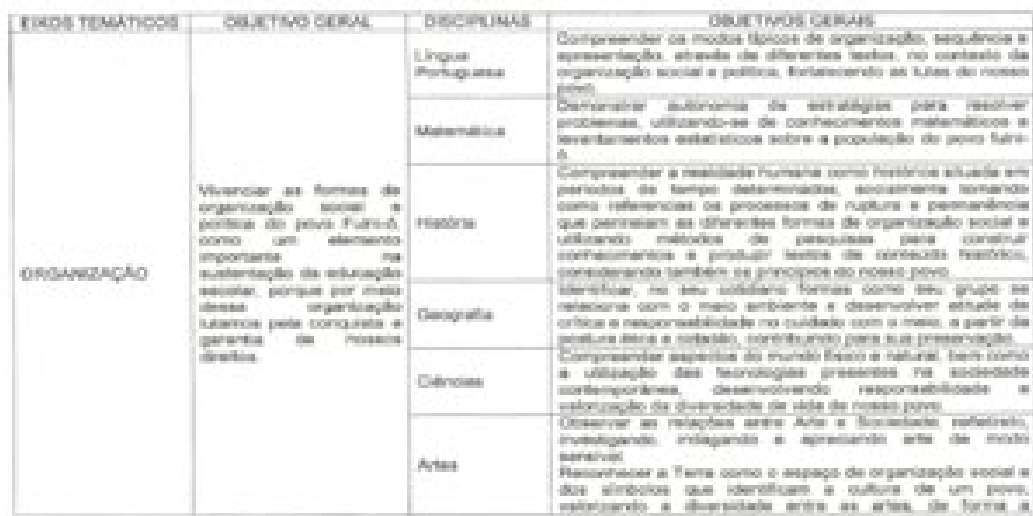




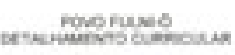

\begin{tabular}{|c|c|c|c|}
\hline \multirow{5}{*}{ netions } & \multirow{5}{*}{ 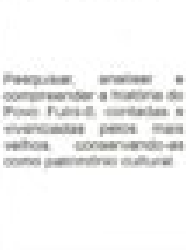 } & Sicions & 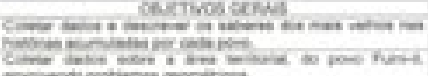 \\
\hline & & $\infty$ & $m-2 n=7-105$ \\
\hline & & ons & 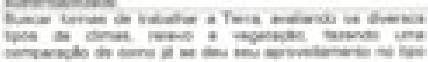 \\
\hline & & - & $-10-1-100$ \\
\hline & & $t a=$ & $m-1-2-15$ \\
\hline
\end{tabular}

pevonuses
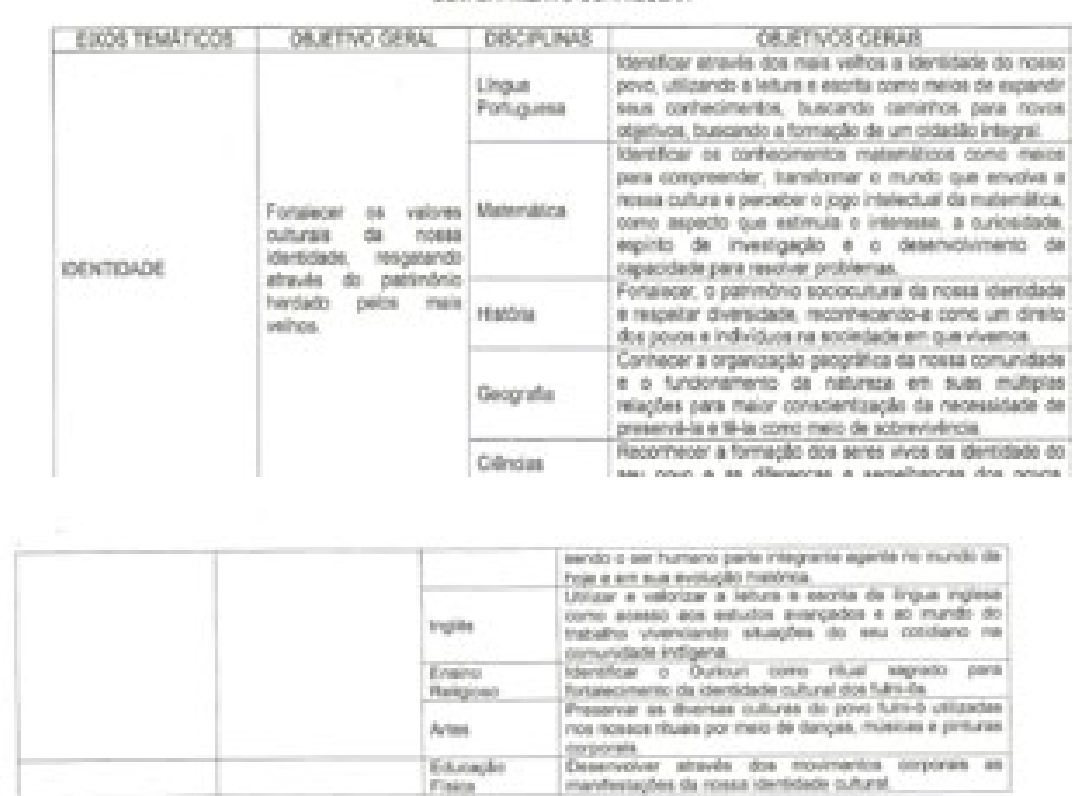

mosper

\begin{tabular}{|c|c|c|c|}
\hline reormances: & const & & oe \\
\hline & \multirow{7}{*}{ 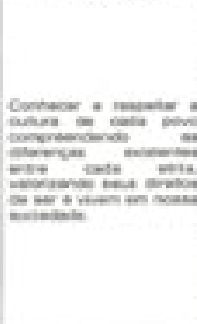 } & Her. & 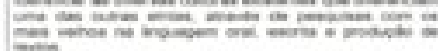 \\
\hline & & nanter. & 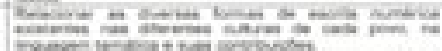 \\
\hline & & $n=0$ & $\approx \approx-15 \pi=5$ \\
\hline & & 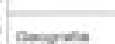 & 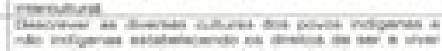 \\
\hline & & cotcis & 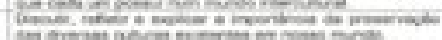 \\
\hline & & - & $\therefore-2=-1$ \\
\hline & & $=$ & $x+2=-2=-1$ \\
\hline
\end{tabular}

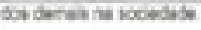




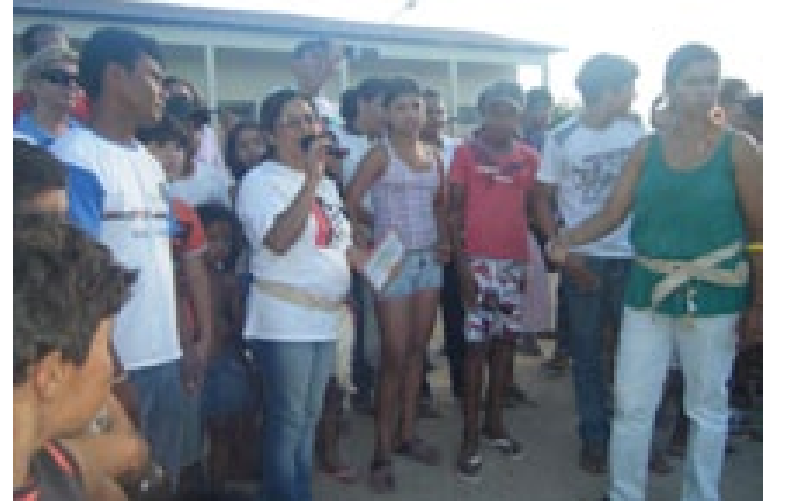

Fotografia 4: Coordenadora Geral das Escolas de Fulni-ô Maristela Albuquerque em apresentação na escola em maio de 2010.

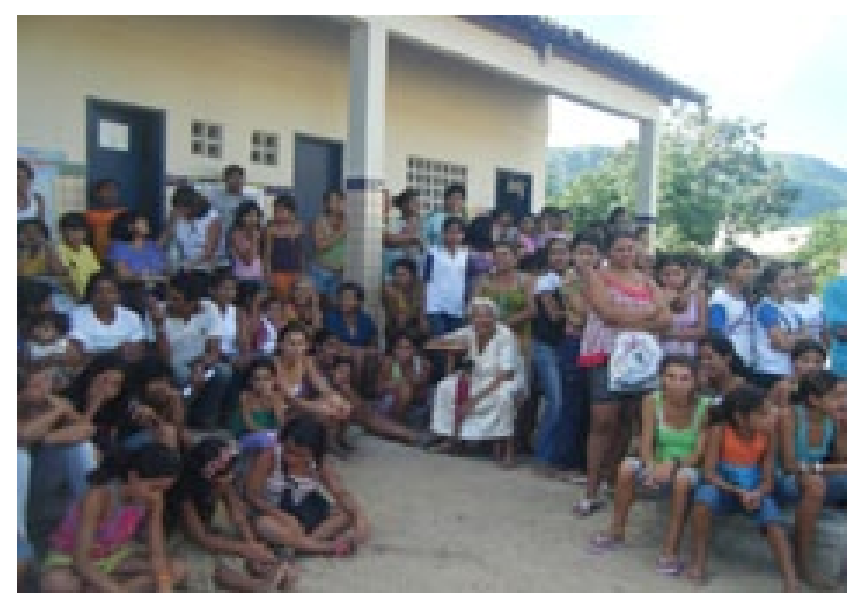

Fotografia 5: Comunidade Escolar da Escola Indígena Fulni-ô Marechal Rondon durante a exposição na escola em maio de 2010.

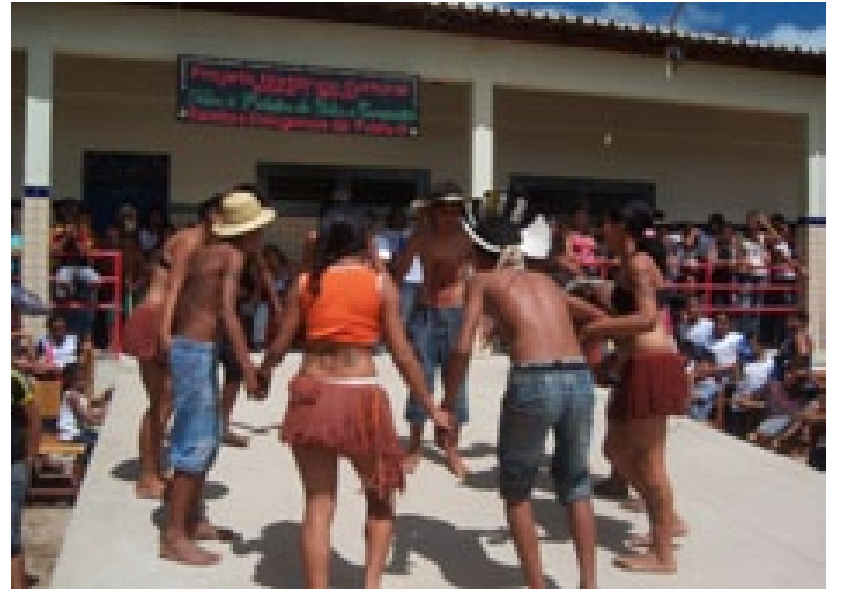

Fotografia 6: Grupo de dança com estudantes da Escola Indígena Fulni-ô Marechal Rondon em maio de 2010

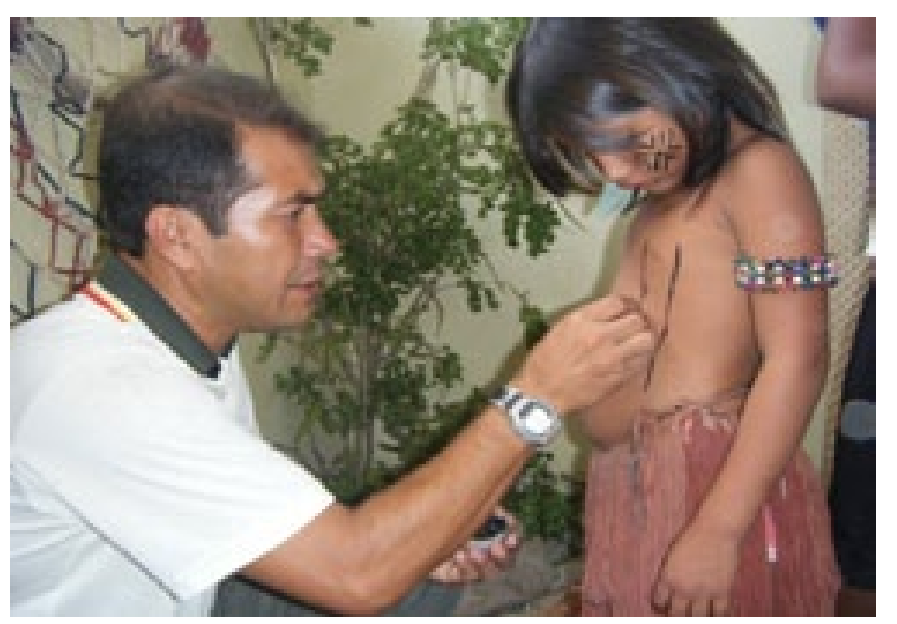

Fotografia 7: Professor e estudante da Escola Indígena Fulni-ô Marechal Rondon realizando pintura corporal. 


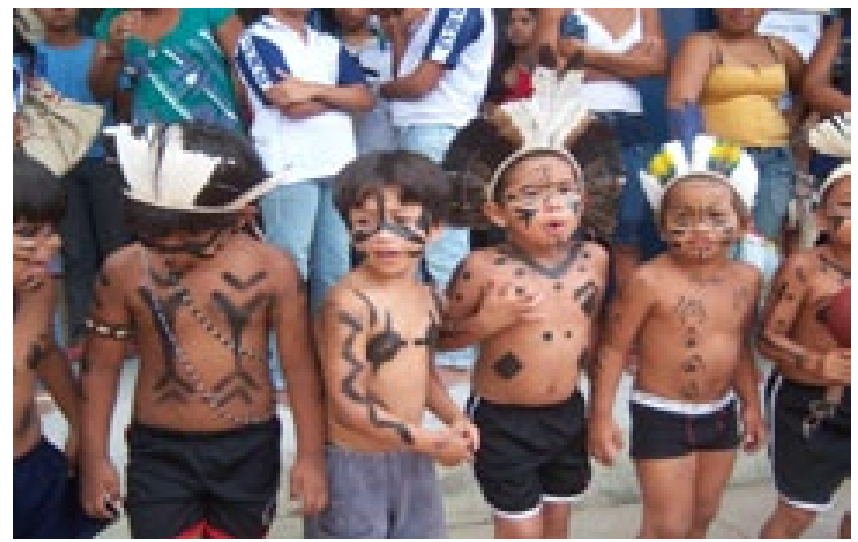

Fotografia 8: Fotografia dos educandos da Escola Indígena Fulni-ô Marechal Rondon em atividades de dança e cânticos em maio de 2010.

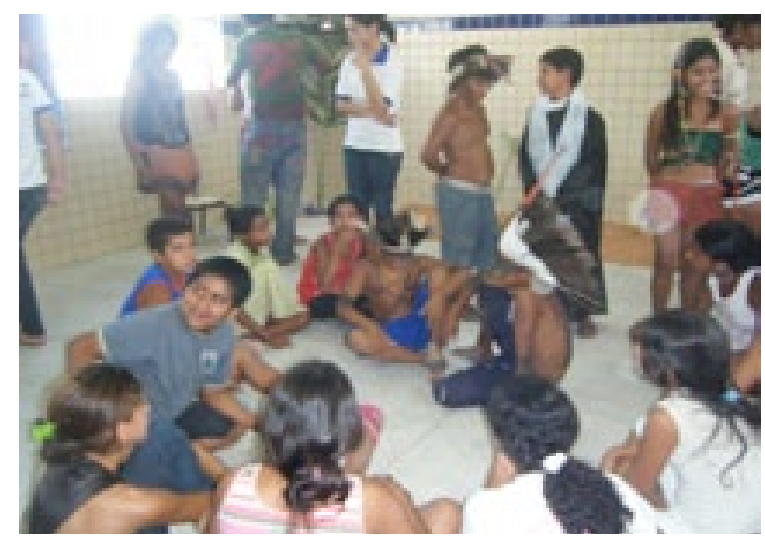

Fotografia 9: Estudantes da Escola Indígena Fulni-ô Marechal Rondon em apresentação teatral em maio de 2010

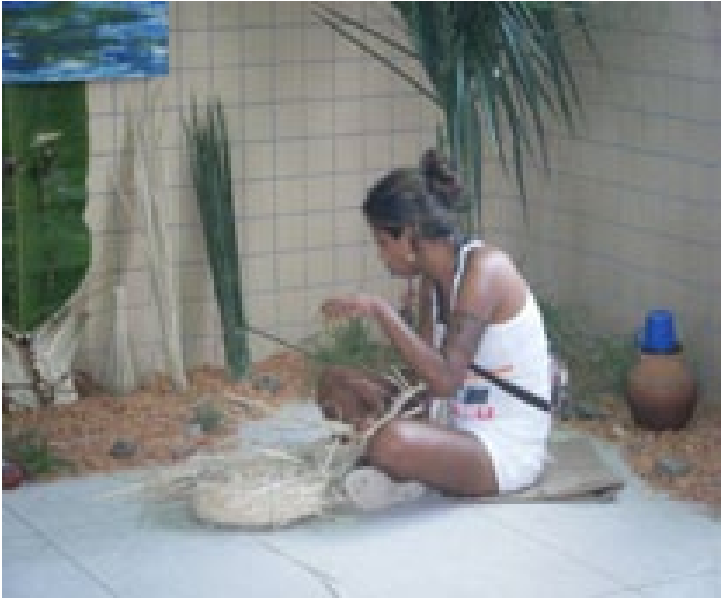

Fotografia 10: Estudante da Escola Indígena Fulni-ô Marechal Rondon produzindo artesanato em maio de 2010

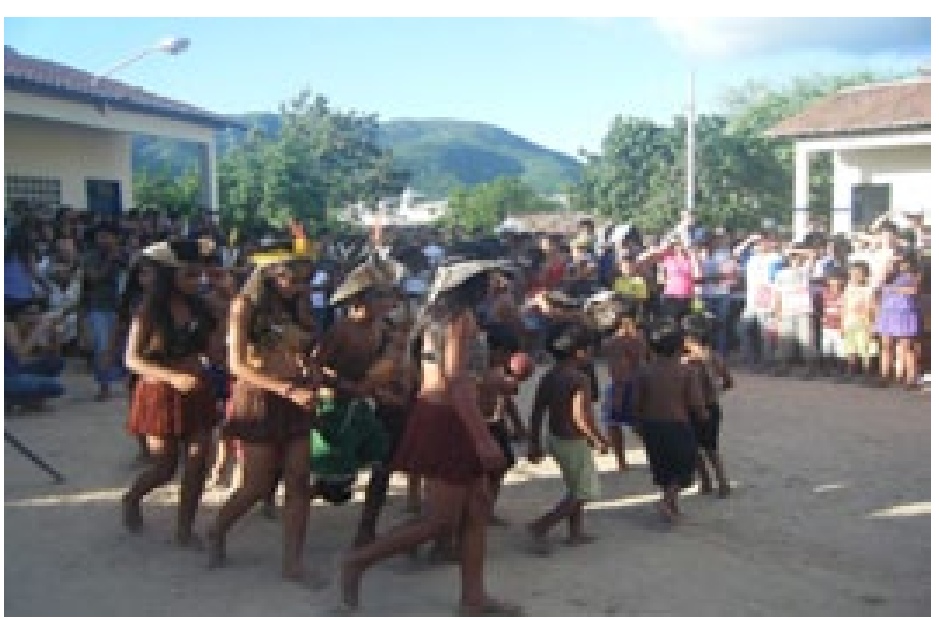

Fotografia 11: Estudantes da Escola Indígena Fulni-ô Marechal Rondon em apresentação de canto e dança em maio de 2010. 

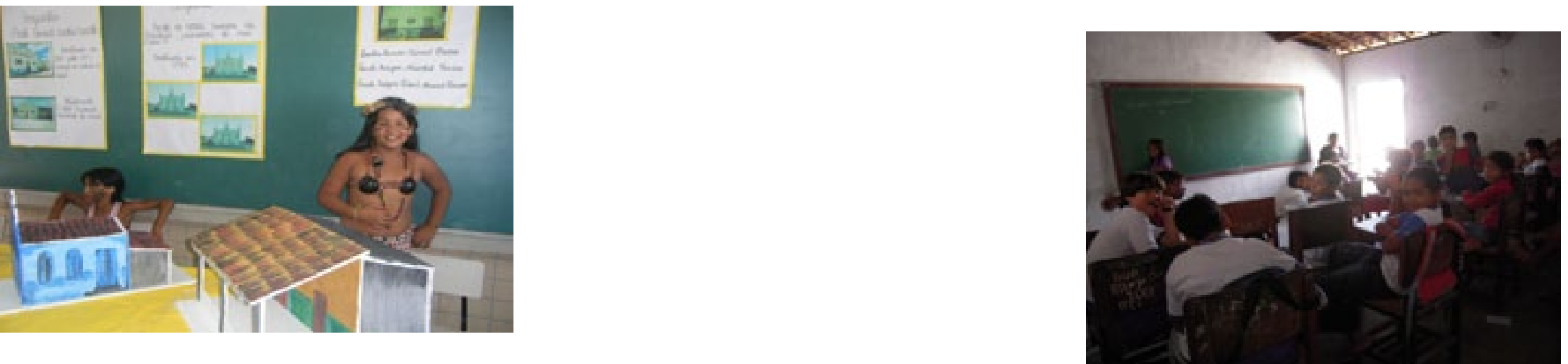

Fotografia 12: Estudantes da Escola Indígena Fulni-ô Marechal Rondon apresentando a história do seu povo em maio de 2010.

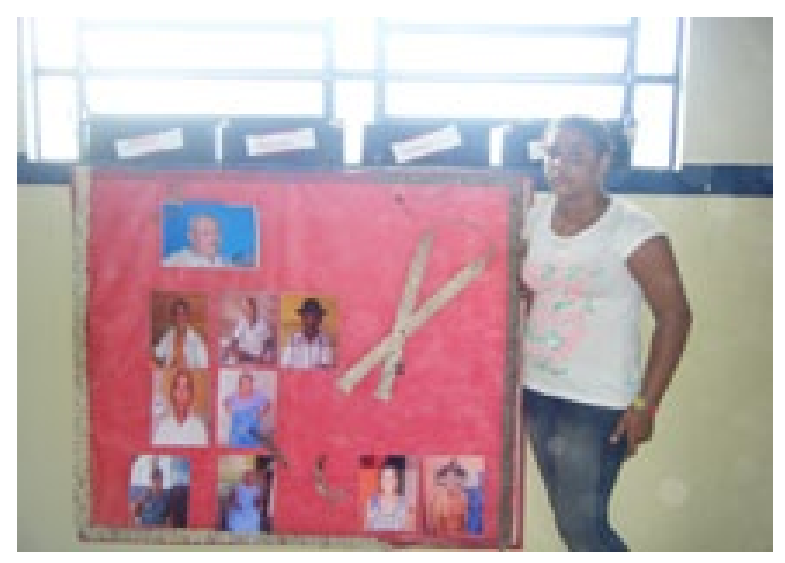

Fotografia 13: Estudante da Escola Indígena Fulni-ô Marechal Rondon expondo seu trabalho sobre as lideranças da etnia em maio de 2010.
Fotografia 14: Sala de aula e educandos da professora Paula Francisca de Souza na Escola Indígena Fulni-ô Marechal Rondon em agosto de 2010

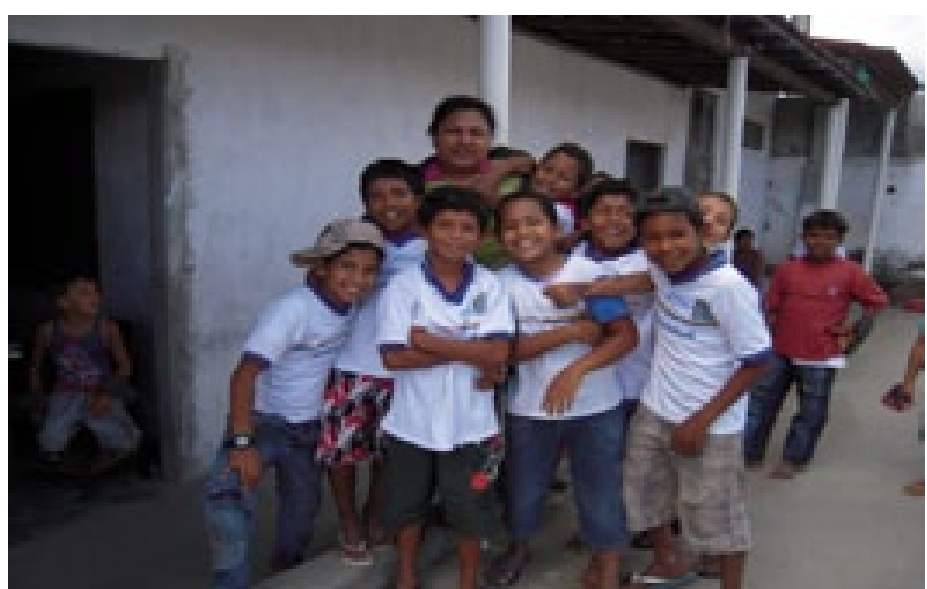

Fotografia 15: Professora Paula Francisca de Souza e seus educandos na Escola Indígena Fulni-ô Marechal Rondon em agosto de 2010. 


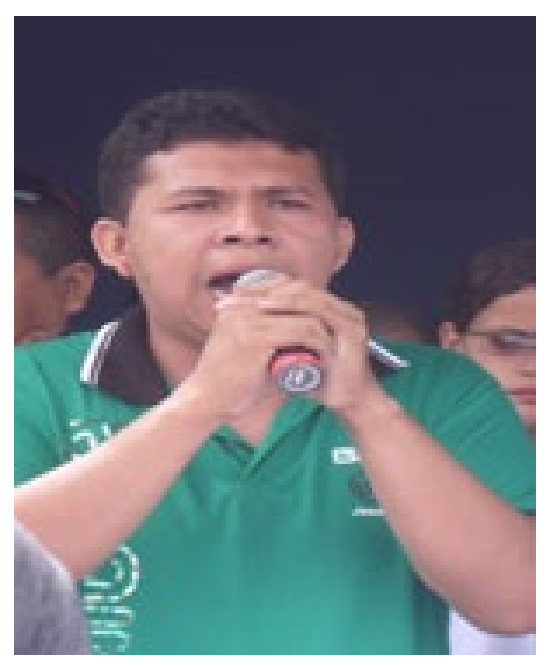

Fotografia 16: Gildiere Ribeiro Pereira - Pajé da etnia Fulni-ô e professor de Língua Materna - Yaathê

\section{APRENDIZAJE \\ Y COMPETENCIAS \\ INTERCULTURALES}

Alessio Surian alessio.surian@unipd.it

\section{Resumen}

El concepto de competencia intercultural es asociado en la literatura tanto a listas de habilidades que permiten tener "éxito" como individuo y como organización en las relaciones transculturales, como visiones más criticas e interesadas a los diferentes contextos y papeles sociales que juegan un rol en la definición y percepción de estas relaciones.

Al concepto de competencia intercultural autores como Earley y Ang (2003, p. 59) prefieren el concepto de inteligencia cultural, en relación a como las personas saben adaptarse a nuevos contextos culturales, y en continuidad con el trabajo sobre inteligencias de psicólogos de la educación (H. Gardner, R.J. Sternberg), y en relación a la interacción entre estilos cognitivos y gestión de las actividades cotidianas (Zhang, Sternberg, 2001, pp. 198-200).

A partir de enfoques diferentes, se ha producido en los últimos años un numero significativo de herramientas de evaluación de las competencias interculturales (Earley y Ang 2003, pp. 193-199; Fowler y Blohm 2004, pp. 37-84; Paige 2004, pp. 85-128).

En esta contribución se investigan los aspectos relevantes y las implicaciones de los discursos sobre competencias interculturales para los procesos de aprendizaje y para las políticas de educación que integran un enfoque intercultural.

Palabras claves: relaciones transculturales; políticas de educación Key words: crosscultural relations; educational policies 